\title{
Spatial Modeling on Coastal Land Use/Land Cover Changes and its Impact on Farmers
}

\author{
Bambang Riadi',, ${ }^{1,}$ Baba Barus², Widiatmaka ${ }^{2}$, M Yanuar $\mathrm{JP}^{3}$, Bambang Pramudya ${ }^{4}$ \\ ${ }^{1}$ Natural Resources and Environmental Management, Bogor Agricultural University, Indonesia \\ ${ }^{2}$ Department of Soil Science and Land Resources, Bogor Agricultural University, Indonesia \\ ${ }^{3}$ Department of Civil and Environmental Engineering, Bogor Agricultural University, Indonesia \\ ${ }^{4}$ Department of Agroindustrial Technology, Bogor Agricultural University, Indonesia
}

Copyright@2018 by authors, all rights reserved. Authors agree that this article remains permanently open access under the terms of the Creative Commons Attribution License 4.0 International License

\begin{abstract}
Coastal areas are an attractive place to live and/or to perform community activities, therefore coastal areas are vulnerable to both natural and artificial damage and destruction. This study presents the problem of changes in land cover/land use in coastal areas caused by humans. Rapid environmental change due to population growth will require food, shelter and other infrastructure. The $2010-2015$ population growth rate of $1.37 \%$ or the population grew $6.86 \%$ from 2010 . Population growth and industrial development increased demand for housing, roads and industrial infrastructure that encouraged land conversion. Agricultural land is the most converted land. Land use in 2000, for paddy fields area was 120,371 ha (62.83\%) and pond area was 4,484 ha (2.34\%). In 2015 paddy fields were degraded to 98.462 ha (51.41\%), and pond area to 20,839 ha (10.88\%). Markov modeling had a correlation of $97.72 \%$ " $r$ " square value, indicated this modeling could be done to predict land cover change until 2031. In an effort to optimize irrigation field potential and increase of farmer's income, minapadi system (combined farming/fish kept in the paddy fields) was done by previous monoculture farmers to diversification system agriculture. This pattern could increase the productivity of the land and also could increase the diversity of agricultural produce, increase farmer income, increase soil fertility, and also reduce pest disease in rice plants. The purpose of this study is to model spatial changes in land cover/coastal land use and its effect on rice production, fish paddy field production and fishpond production in coastal habitat.
\end{abstract}

Keywords Minapadi, Karawang, Markov, Paddy Fields, Ponds

\section{Introduction}

Population growth in Karawang regency averages
$1.37 \%$ per year.This population condition is followed by an increase in settlement infrastructure such as transportation facilities, fresh water and others. Settlement infrastructure and population growth have become triggers for the land conversion in coastal areas for settlements and other economic activities. Changes in agricultural land use and fisheries, identification of flood areas and estimates of agricultural production can be analysed using a remote sensing techniqueas one of the geospatial-based alternative approaches.

Presidential Decree no. 53 year 1989 about the industrial area directed development of industrial estate in Kabupaten Karawang, and it became the starting point of agricultural land conversion to industry. The paddy fields in Karawang regency in 2000 was 120,371 ha (62.83\% of the regency), while in 2015 the remaining paddy fieldswas 98,462 ha (51.39\%), meaning that in the period of 2000-2015 there has been conversion of paddy fields by 21,909 ha. From various land uses, the most converted one was paddy fields, especially around urban and settlement development centers [1]. In general, the paddy fields were transformed into settlements, ponds, urban areas and industries. A rapid pace of development programs and population increases led to rapid conversion of the rice fields.

When the aquaculture intensification program has improved and resulted in increased production and net income of farmers, there was an increase in demand for ponds in productive areas, therefore the selling price and the price of ponds became high [2]. The impact of expansion of ponds tended to shift natural ecosystems such as mangrove forests and paddy fields. Aquaculture is a maintenance activity and enlargement of aquatic biota in pond waters within a certain time to get the harvest. Changes land function in the area of mangrove and paddy fields to be ponds conducted by the surrounding community is to meet the needs of fish farmer life [3].

Another program conducted in coastal areas is called 
minapadi system (combined farming where fishes are kept in the paddy fields). For this system pond is made around a paddy field with a width of one meter and a depth of 60 centimeters, thus reducing area of the paddy field by about $10 \%$ to $20 \%$. Although paddy fields are reduced for fish ponds, overall income is more favorable [4]. The minapadi system can reduce labor costs especially for weeding (to clean weeds around cultivated plants), because weeds have been eaten by fish. Although the pond is set up for the fishes, they can still swim among paddy plants when paddy fields are filled with water. This minapadi uses 'ecosystem approach' and will gradually eliminate dependence on pesticide use.

Analysis of land use change was performed by overlaying thematic maps in 2000, Landsat image in 2006 and Landsat image in 2015. The basic thematic map was compiled from the result of land cover extract from topography map of year 2000. Landsat image in 2006 was used as basis for updating map of 2000, resulting as a thematic map of 2006. Landsat images in 2015 were analyzed using Tasseled Cap Transformation (TCT) method. To recognize wetland as an indication of flood hazard areas, the Topographic Wetness Index (TWI) method was used. TWI was processed using TerraSAR-X DTM data. Flood hazard maps covered with land cover thematic maps would provide information on flood hazard areas that could have an economic impact on farmers. The Markov method was used to calculate the projection of land use degradation up to 2031. The purpose of this research was to analyze land use/land cover changes in coastal area and its effects on coastal habitat and existence of flood hazard.

\section{Materials and Methods}

The study was conducted in Karawang Regency, located in between $107^{\circ} 02^{\prime}-107^{\circ} 40^{\prime}$ East and $5^{\circ} 56^{\prime}-6^{\circ} 34^{\prime}$ South. Location of the study is shown in Figure 1. Karawang regency is located in coastal zone having lowland morphologyandan average air temperature of $27^{\circ} \mathrm{C}$. Variations of slope in the region were between $0 \%$ to $2 \%$, $2 \%$ to $15 \%$ and a small part with slope above $40 \%$. Elevation of the northern region was between 0 to $25 \mathrm{~m}$ mean sea level (msl), while a small part of the southern region had an elevation of $26 \mathrm{~m}$ to $1200 \mathrm{~m}$ msl, and the region had an annual mean rainfall of $728 \mathrm{~mm}$ [5].

\subsection{Materials}

Materials used in this study include Topographic map scale 1:25.000 year 2000, Landsat TM Image year 2006, Landsat 8 OLI year 2015, DTM TerraSAR-X year 2011, statitical data and field survey data. The software used in this study were Microsoft Office 2010, Global Mapper V.10, ER Mapper 7, Idrisi, Ilwis 3.85 and ArcGIS 10.2.2.

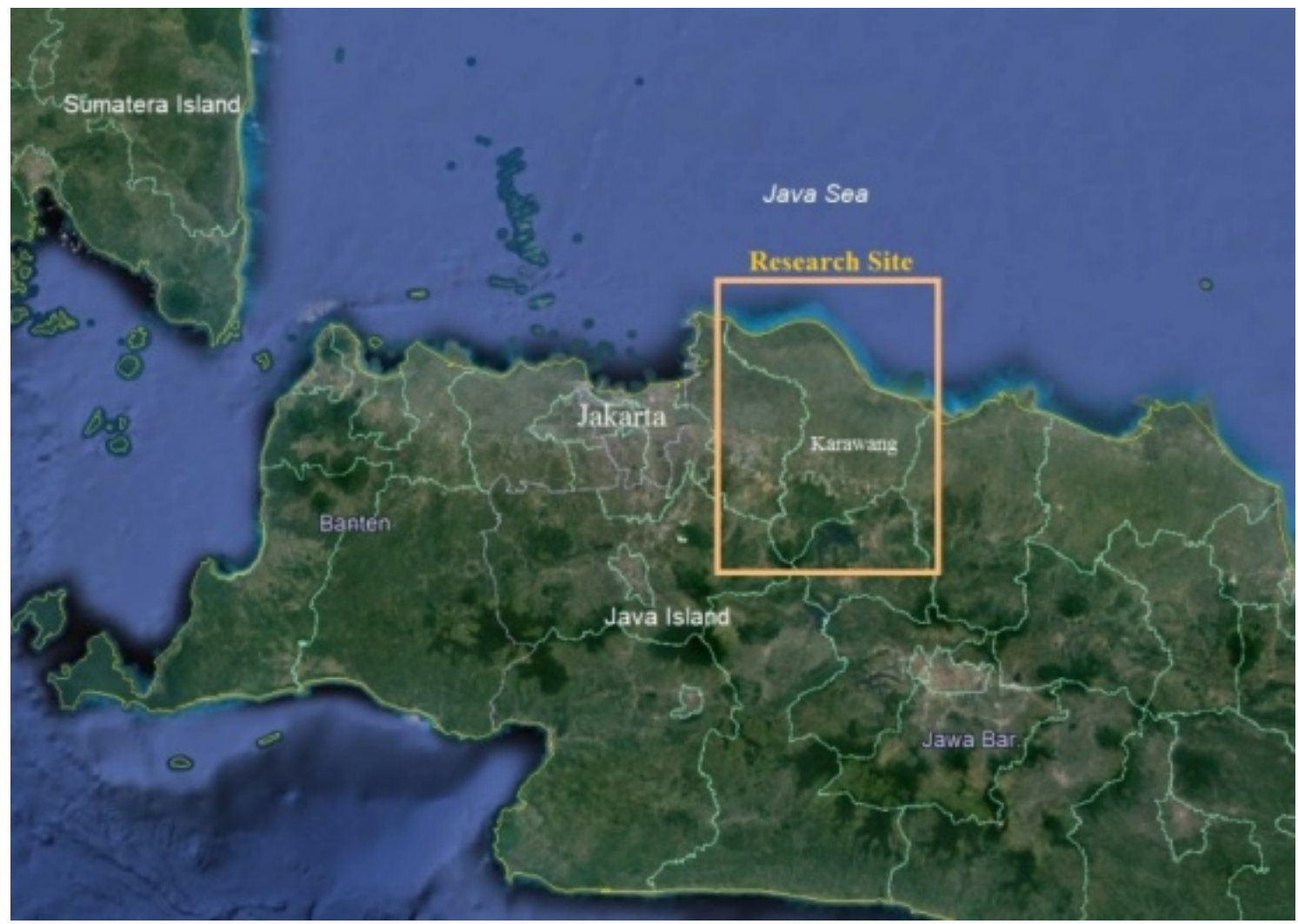

Figure 1. Research location map 


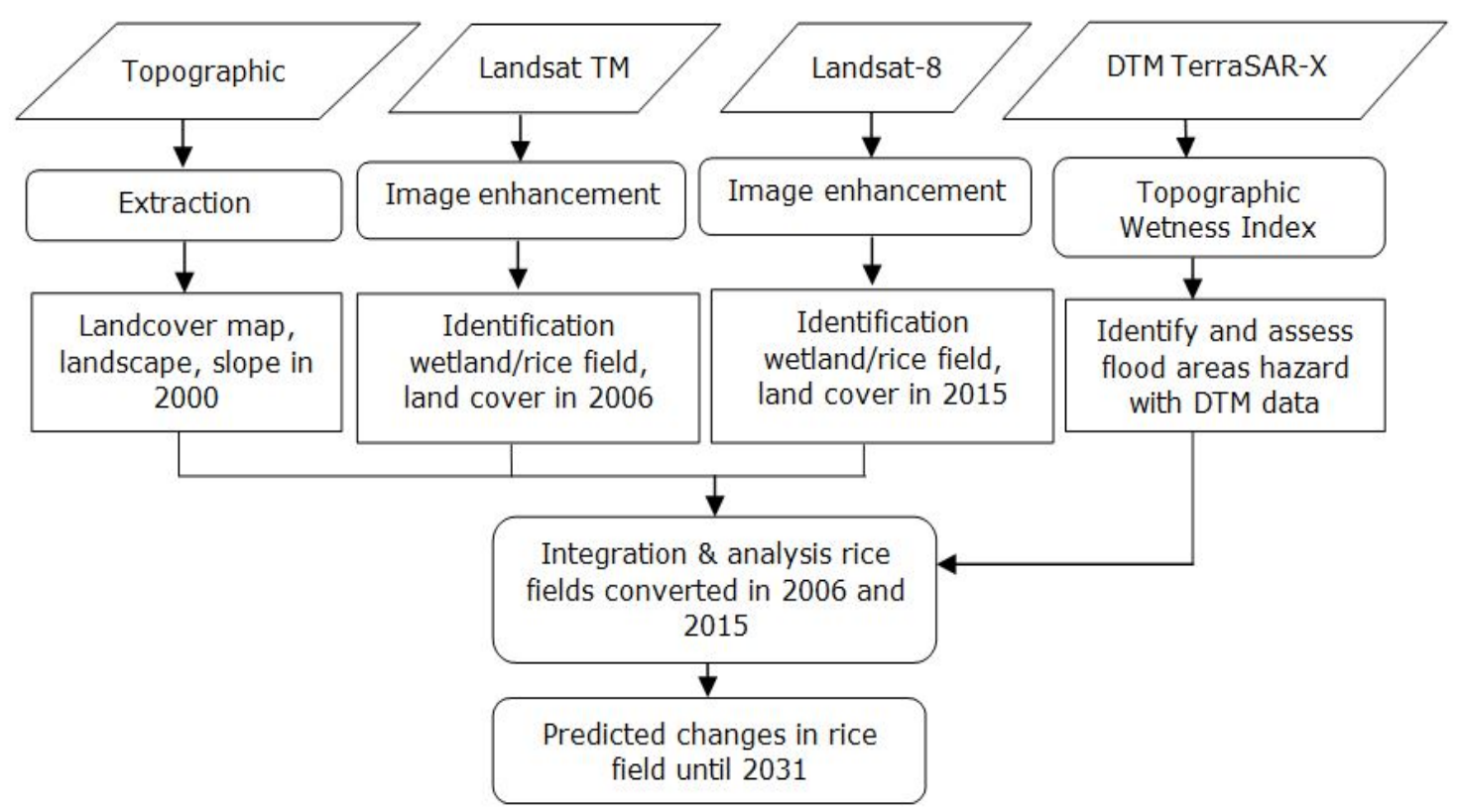

Figure 2. Flow chart of research methods

\subsection{Methods}

Statistical data were collected from Central Bureau of Statistics and some other government institutions in Karawang Regency. Spatial data were collected from Geospatial Information Agency (Topographic map in 2000 and DTM TerraSAR-X in 2011), Landsat TM year 2006 and Landsat-8 images year 2015 were downloaded from [6]. Further analysis was carried out to determine the landcover area in 2000, 2006, and 2015. The landcover data was obtained from image enhancement using TCT (Tasseled Cap Transformation). Flood hazard areas were identified using TerraSAR-X DTM data using TWI (Topgraphic Wetness Index) method. The TWI analysis described an area with flood hazard potential or an area with flood potential that could be assumed to have a high probability of flooding [7]. Projected future land cover changes were made using the predicted changes in the present approach through spatial modeling (Figure 2). The prediction model used CA-Markov to predict future land use changes by simulating land cover changes [8]. Degradation of paddy fields resulted in a lower rice production, and expansion of ponds on the other hand increased fishery production. Losses due to crop failures could be calculated based on the area of crop failure of rice or fish multiplied by productivity.

\subsection{Data Analysis}

Coastal Cultivation. The development of coastal aquaculture has given importance to fishery sector. The extent of the pond has increased its distribution and this can be observed spatially. Cultivation activities open employment and provide income to farmers and their families. The pond has become an important economic resource in coastal areas. The generally extensive coastal areas are suitable for expansion of ponds. Based on the results of the study on the physics - chemistry of waters, there was a tendency of excessive organic waste that could disrupt the aquaculture activities. However, in general the condition of both freshwater and marine waters in the coastal region of North Karawang was not too bad and therefore could be utilized for coastal aquaculture activities [9].

The study area is highly potential for rice cultivation and is a national rice barn located in coastal area. This area is also potential for terrestrial fisheries in minapadi system (combined farming / fish are kept in the paddy fields). Minapadi method is done by making a pond around the paddy field and use water in the fields as a medium for thefish. One week after fertilization of rice crops, the pond was filled with water up to a height of $50 \mathrm{~cm}$, then the seeds of the fish were spread with a density of 3-4 fish $/ \mathrm{m}^{2}$. Fish seeds used were tilapia (Oreochromisniloticus) ofsize 3-5 $\mathrm{cm}$. The fish was harvested when its size reached $5-8 \mathrm{~cm}$ (phase of enlargement) or when the duration of fish nourishingwas 60 days [10] (Ashuri 2011).

Projected Population. Based on population data in 2010-2015, the average population growth rate (r) during 5 years was $1.37 \%$. Using the Arithmetic Linear formula [5] and [7] (BPS 2016 and Riadi et al, 2017), projected population growth in the following years could be calculated with the following formula:

$$
P t=P o(1+\mathrm{r})^{\mathrm{t}}
$$

$\mathrm{Pt}=$ Number of residents in the final year; $\mathrm{Po}=$ Population in the base year; $\mathrm{t}=$ Time period; $\mathrm{r}=$ Population growth rate $(1.37 \%)$. 
The needs of population consumption of rice per year could be calculated by using the formula:

$$
K K=S K x P t
$$

Conversion of grain to rice was $62.74 \%$ (BPS, 2016)

$$
K G=K K x 100 / 62.74
$$

$\mathrm{KK}=$ Needs of rice consumption of the population; $\mathrm{SK}=$ Standardconsumption(kg/ capita/year); $\mathrm{Pt}=$ Population year (Projected population $\mathrm{t}$ year); $\mathrm{KG}=$ Grain Consumption

Land Used/Land Cover Changes Analysis. The land cover thematic maps were extracted from topographic maps of scale 1: 25,000 in 2000. This extracted map would serve as an initial reference for spatial analysis. The Landsat TM image was analyzed with an enhancement process to update the basic thematic maps, resulting in a 2006 land cover map.

Landsat-8 Image Record data on October 18, 2015 performed an enhancement process by transforming the Tasseled Cap Transformation (TCT) spectral values. Tasseled Cap Transformation (TCT) is a mathematical formula to calculate the levels of brightness, greenness, and moisture (wetness) of digital numbers in each band (band 1 to band 5 and band 7) on Landsat imagery. The mathematical formulation of third components TCT $[11,7]$ are expressed in the following three equations for Landsat 8.

The Tasseled Cap Transformation Formula (4)

$$
\begin{aligned}
\text { Brightness }= & B 2 * 0.3029+B r * 0.2786+B 4 \\
& * 0.4733+B 5 * 0.5599+B 6 * 0.508 \\
& +B 7 * 0.1872 \\
\text { Greenness }= & B 2 *-0.2941+B 3 *-0.243+B 4 \\
& *-0.5424+B 5 * 0.7276+B 6 \\
& * 0.0713+B 7 *-0.1608 \\
\text { Wetness }= & B 2 * 0.1511+B 3 * 0.1973+B 4 \\
& * 0.3283+B 5 * 0.3407+B 6 \\
& *-0.7117+B 7 *-0.4559
\end{aligned}
$$

where B1 = Band1, B2= Band2, B3= Band3, B4= Band4, $\mathrm{B} 5=\mathrm{Band} 5, \mathrm{~B} 7=$ Band7.

Identification of Flood Area. TerraSAR-X signals have sensitivity to wet areas, thus an increase in wetness of an area may indicate a flood hazard area [12]. Terra SAR-X DEM data were analyzed using topographic Wetness index (TWI) method [13].The Topographic Wetness Index is a wetness index determined from the previously calculated surface variables with the following equation:

$$
T W I=\ln \frac{\alpha}{\tan \beta}
$$

Where $\alpha=$ Flow Accumulation and $\tan \beta$ are slopes.

In general, the delineation result of boundary areas of flood hazard needed to be generalized by conducting selection, simplification, merging, and magnification. Selection was done for objects that need to be eliminated and/or combined, because they did not meet geometry specifications or did not fit into the classification of elements that can be displayed on the map scale. Selection was done by removing and / or aggregating segments of polygon at least $0.5 \mathrm{~mm} \times 0.5 \mathrm{~mm}$ [14]. TCT maps, when overlayed with TWI maps, will show the distribution of flood hazard areas. An area was considered having high flood hazard when the flooding frequency occured each year, inundation height was over $70 \mathrm{~cm}$ and flood duration was more than 7 days.

Land use/Land cover Modeling. Geographical Information System technology provides a number of spatial analyzes that can be used to determine trends in land cover changes in a region [15]. Projected future land cover changes are made with the predicted changes in the present approach through spatial modeling. The prediction model uses CA-Markov, to predict land use changes in 2031. This software has the ability to simulate land cover changes with Markov chain procedures [8]. The first simulation used as a prediction model was the land use/land cover in 2000 and 2006 to predict land use/land cover in 2015. The results of the 2015 land cover change model were validated using linear regression to the 2015 land cover map. If the modeling had a good correlation, similar method would be used to predict land cover modeling until 2031.The model was based on land cover map of 2000, 2006 and land cover map of 2015. The data used in this process wasin raster format with a pixel size of 30x30 meters.

\subsection{Result}

Coastal Cultivation. Aquaculture is one of the coastal fisheries businesses, such as shrimp cultivated commodity (Penaeusmonodon or Litopenaeusvannamei) and milkfish (Chanoschanos), with average management of 10 ha per fish farmer. Revenue earned by farmers was sufficient to meet the needs of family members, farmers became prosperous because the income and profit of the pond production was quite high [16]. Increased fishery swamp production (Table 1) indicated that pond farming had a high economic value for fish farmers. Pond cultivation was conducted on an area of 18,273 ha [5].

Table 1. Ponds Fishery and Paddy Filed Fishery Production (tons)

\begin{tabular}{|c|c|c|}
\hline Years & Production fish ponds & Production fish paddy field \\
\hline 2010 & $35,101.19$ & 671.47 \\
\hline 2011 & $35,267.54$ & 409.80 \\
\hline 2012 & $35,285.15$ & 364.17 \\
\hline 2013 & $36,648.48$ & 360.87 \\
\hline 2014 & $37,839.70$ & 273.64 \\
\hline 2015 & $39,113.65$ & 293.62 \\
\hline
\end{tabular}

Source: [5] 
During rainy season Minapadi system gets more than enough fresh water from the rain, while during dry season the availability of fresh water is limited, so there are differences in fish production for different seasons. Generally, economic analysis result shows that break event point value for paddy production and production of fish in paddy field obtained $\mathrm{B} / \mathrm{C}$ ratio of 1.4(comparison between profit and business costs), whichmeans that every 1 (IDR) issued will get revenue of 1.4 (IDR). Minapadi system is one of the prospective business segments conducted by farmers and fish farmers [10]. Minapadi cultivation is done in a paddy field with an area of 11,273 ha.

Population Growth in Karawang Regency and rice consumptionneed. The population growth of Karawang regency averages $1.37 \%$ per year and rice production in 2015 was 1,489,429 tons. The population in 2015 was 2,273,579 people with rice consumption of 98.5 $\mathrm{kg} / \mathrm{capita} /$ year (BPS, 2016). Therefore, the need for rice was 223,947 tons or equivalent to 356,945 tons of grain. Thus, in 2015 the grain surplus in Karawang regency was $1,489,429$ tons minus 356,945 tons, which was equal to $1,132,484$ tons or equivalent to 710,520 tons of rice. Projected population growth until 2031 was calculated using Formula 1The population of Karawang regency is $2,826,579$ people in 2031 or increase the population by $24.3 \%$. The need for rice was 278,418 tons or equivalent to 443,765 tons of grain.

The results showed that the population density was unequally distributed and concentrated in urban areas with a density of $>1500$ persons $/ \mathrm{km}^{2}$ (Figure 4.), population growth would require settlements and land adjacent to urban areas were paddy fields. Population and urban growth as one of the driving forces of land used change.

Land Used/Land Cover Change. From topography map extract, it was found that the area of Karawang regency was 191,577 hectares with paddy field area of 120,371 ha (62.83\%) in 2000 (Figure 3). Landsat TM image analysis for topographic map updated obtained information on paddy field area of 98,462ha (51.41\%) in 2015. (Figure 4), more details are presented in Table 2 .

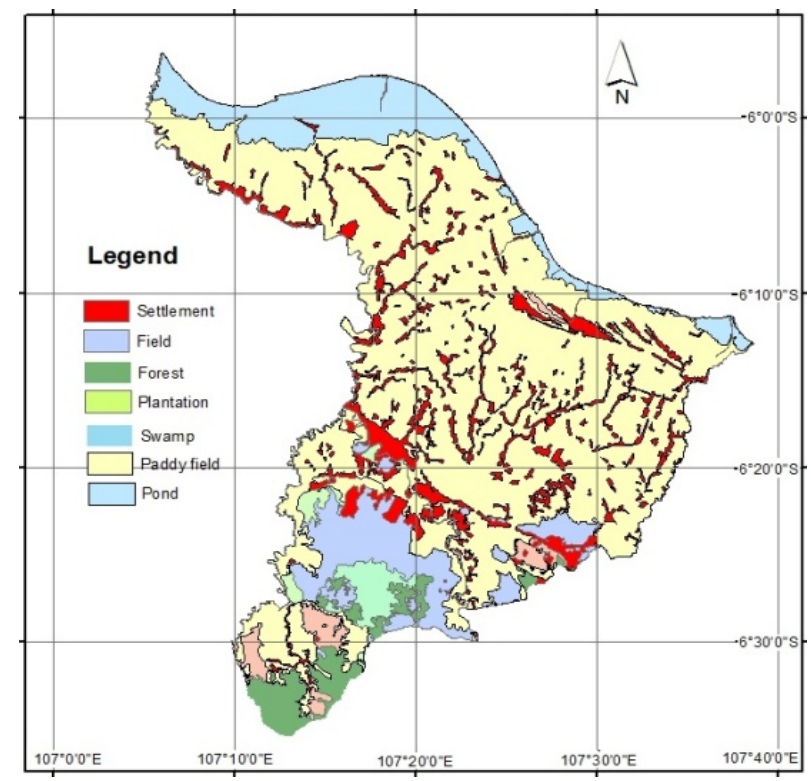

Figure 3. Tematic map in 2000

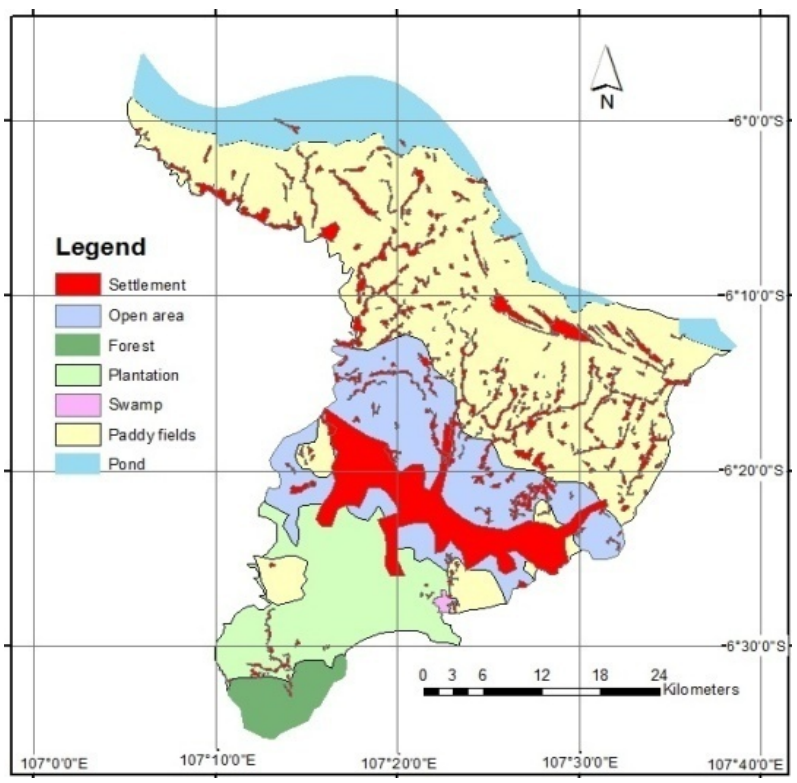

Figure 4. Tematic map in 2015

Landsat-8 image is analyzed by changing spectral valuesusing the Tasseled Cap Transformation (TCT) method yields moisture value information. 


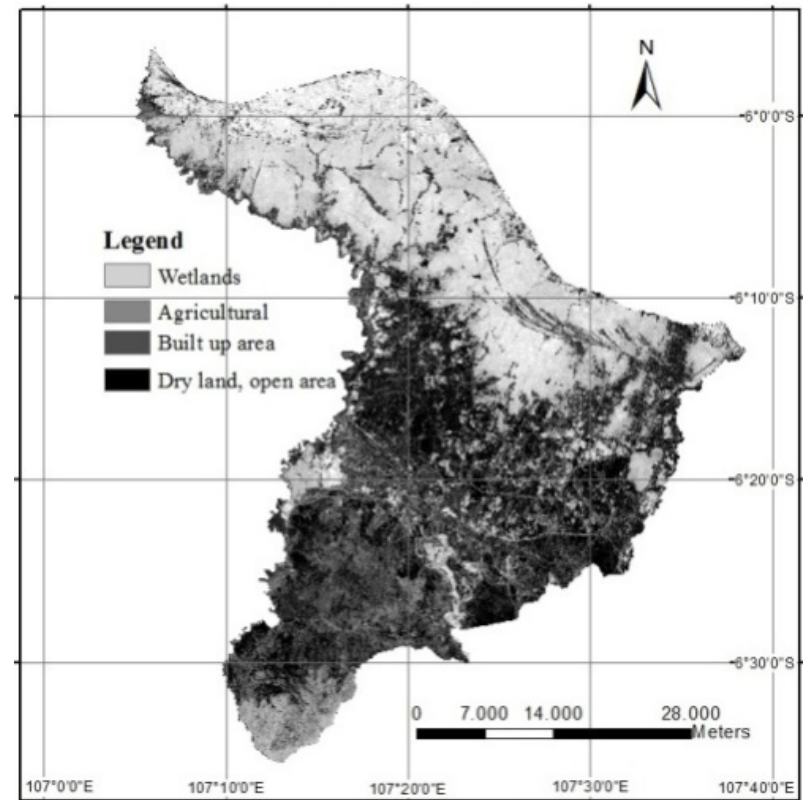

Figure 5. Tasseled Cap Transformation

Tasseled Cap Transformation (TCT) produces three new bands featuring Brightness, Greenness and Wetness. Watering or damp land conditions give a white / sunny look, the darker the indication of dry land. The land with vegetation follows the density of the trees (tight trees look lighter because the soil is moist, the open areas will display darker shades)(Figure 5). Table 2.shows the results of the analysis, which showed that there was a decrease in wetland area from 2000 to 2015.Existing wetland area was 98,462 hectares in 2015.
Land Use/Land Cover Modeling. To predict changes in land use/land cover in the next few years was done by CA-Markov modeling. The result of spatial modeling of land cover changes in 2015 (Figure 6) was validated by linear regression to measure whether the Markov modeling results were correlated with existing land cover or not (Table 3). To improve the accuracy of the modeling added parameters of road elements and population density, road elements will affect the accessibility of the population which will ultimately form the distribution pattern of settlement and distribution of population density.

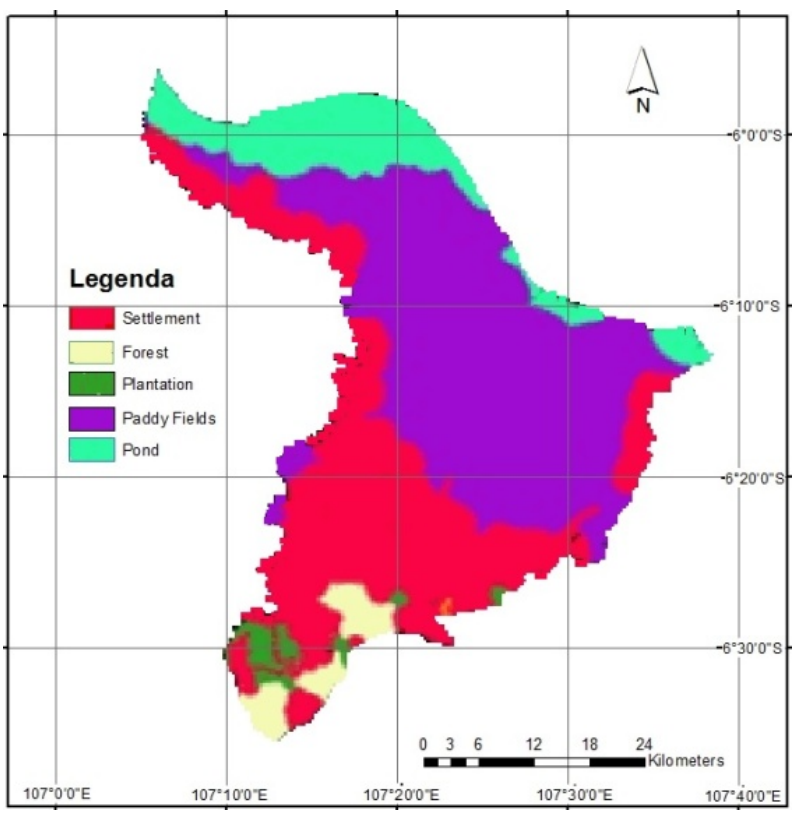

Figure 6. Modeling markov in 2031

Table 2. Land Cover for Period 2000, 2006 and existing of 2015

\begin{tabular}{|c|c|c|c|c|c|c|}
\hline \multirow{2}{*}{ Land Cover } & \multicolumn{2}{|c|}{ Land Cover 2000} & \multicolumn{2}{c|}{ Land Cover 2006 } & \multicolumn{2}{c|}{ Land Cover 2015 } \\
\cline { 2 - 7 } & Area ha & $\%$ & Area ha & $\%$ & Area ha & \% \\
\hline Field, open area & 18,805 & 9.82 & 15,064 & 7.86 & 22,563 & 11.78 \\
\hline Plantation & 5,414 & 2.83 & 13,640 & 6.56 & 11,725 & 6.12 \\
\hline Settlement & 20,301 & 10.60 & 18,757 & 9.79 & 25,611 & 13.37 \\
\hline Forest & 4,836 & 2.52 & 4,905 & 2.56 & 5,556 & 2.90 \\
\hline Mangrove & 2,202 & 1.15 & 310 & 0.16 & 258 & 0.13 \\
\hline Ponds & 4,484 & 2.34 & 12,184 & 6.36 & 20,839 & 10.88 \\
\hline Water body, swamp & 14,325 & 7.48 & 13,836 & 7.22 & 1,311 & 0.68 \\
\hline Paddy fields & 120,371 & 62.83 & 112,878 & 58.92 & 98,462 & 51.41 \\
\hline Industrial area & - & - & - & - & 5,223 & 2.73 \\
\hline Total Area & 191,577 & & 191,577 & & 191,577 & \\
\hline
\end{tabular}

Source: Spatial analysis 
Table 3. Relationship between modeling resultsand existing land cover

\begin{tabular}{|c|c|c|c|c|}
\hline \multirow{2}{*}{ Land Cover } & \multicolumn{2}{|c|}{ Existing 2015} & \multicolumn{2}{c|}{ Result Markov 2015} \\
\cline { 2 - 5 } & Area (ha) & $\%$ & Area (ha) & $\%$ \\
\hline $\begin{array}{c}\text { Settlement, } \\
\text { others }\end{array}$ & 53,426 & 14.36 & 61,007 & 31.75 \\
\hline Plantation & 11,725 & 6.12 & 4,357 & 2.41 \\
\hline Forest & 5,814 & 3.03 & 8,697 & 4.66 \\
\hline Ponds & 20,839 & 10.88 & 24,107 & 12.64 \\
\hline Swamp & 1,311 & 0.68 & 303 & 0.16 \\
\hline Paddy fields & 98,462 & 51.41 & 93,107 & 48.38 \\
\hline
\end{tabular}

Source: Spatial analysis

Markov land cover modeling correlation resulted in a " $\mathrm{R}$ " square value of 0.9772 or $97.72 \%$ (Figure 7), it statedthat $Y$ significantly affected $\mathrm{X}$ for further modeling for land cover change up to 2031 (Figure 8).The variables used in this prediction were settlement, built up area, open area and paddy field. Up to 2031 the remaining paddy fields area was predicted to be $45.81 \%$ (88,007 ha) (Table 4).

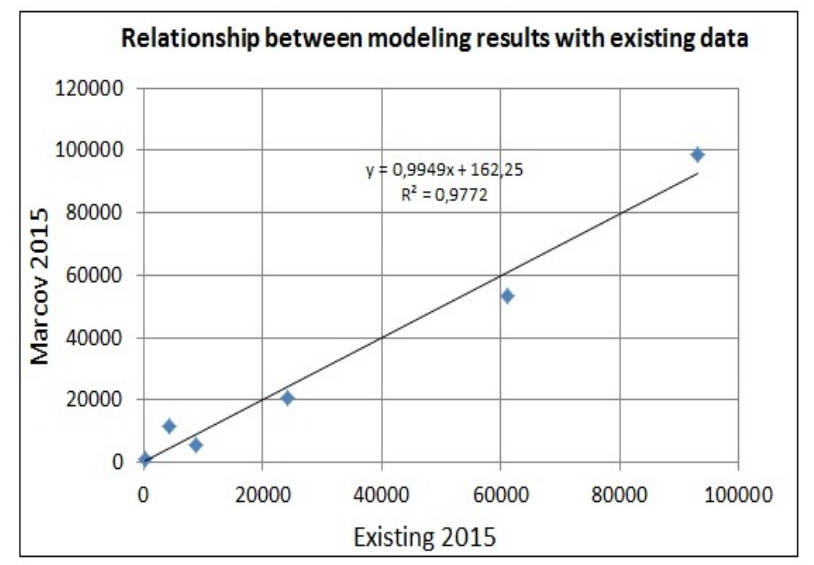

Figure 7. Linear regression of spatial modeling

Table 4. Predicted land cover change up to 2031

\begin{tabular}{|c|c|c|c|c|}
\hline \multirow{2}{*}{ Land Cover } & \multicolumn{2}{|c|}{ Markov 2015 } & \multicolumn{2}{c|}{ Predicted Markov 2031 } \\
\cline { 2 - 5 } & Area ha & $\%$ & Area ha & $\%$ \\
\hline Settlement, others & 61,007 & 31.75 & 65,807 & 34.28 \\
\hline Plantation & 4,357 & 2.41 & 4,457 & 2.42 \\
\hline Forest & 8,697 & 4.66 & 8,697 & 4.67 \\
\hline Ponds & 24,107 & 12.64 & 24,207 & 12.67 \\
\hline Swamp & 303 & 0.16 & 303 & 0.16 \\
\hline Paddy fields & 93,107 & 48.38 & 88,007 & 45.81 \\
\hline Total & 191,577 & & 191.577 & \\
\hline
\end{tabular}

Source: Spatial analysis

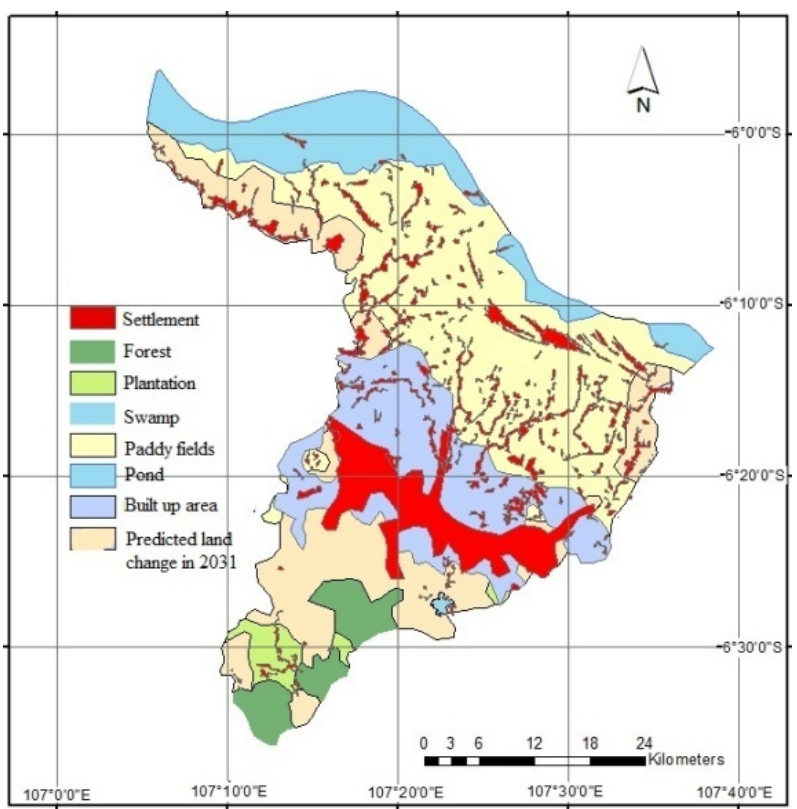

Figure 8. Projected land cover in 2031

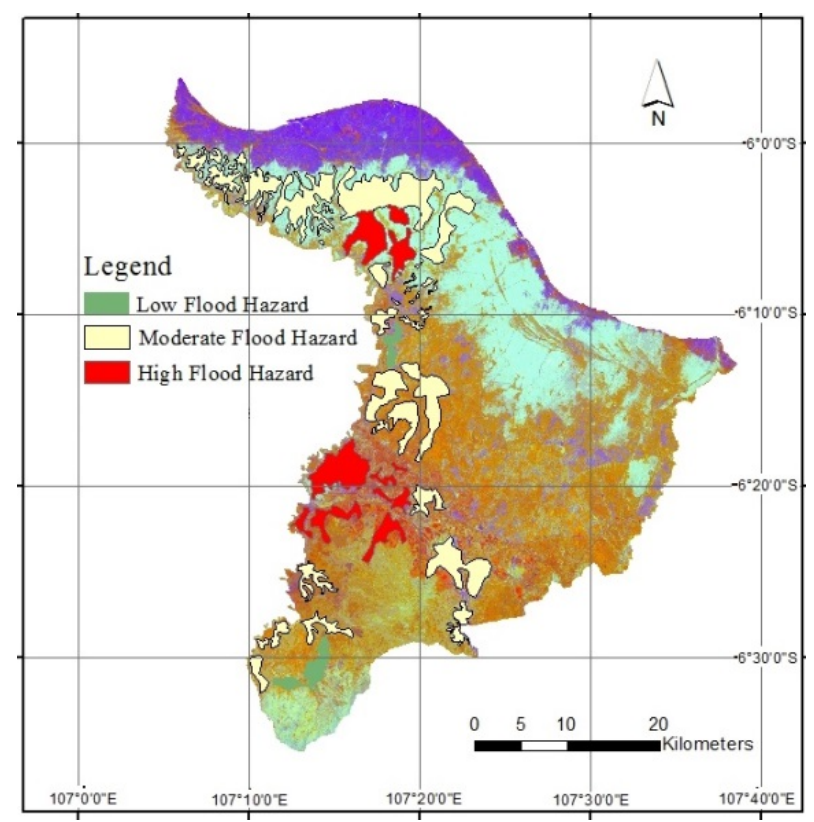

Figure 9. Flood hazard map

Identification of Flood Hazard Areas. The flood hazard area analysis was done by integrating the spatial modeling data of TWI with historical data of flood events. The historical data parameters of flooding in paddy fields consisted of the frequency of flood occurance, the average height of the puddle, and the average length of the inundation.In the overlay. The TWI map was overlaid on the TCT map, by giving the attributes of each parameter in accordance with its influence. The result indicated that the flood hazard in Karawang regency occupied the paddy fields to parts of paddy fields flood area (Figure 9).

From the analysis results, areas with high flood hazard covered an area of 7,489 ha (7.61\%), moderate flood hazard covered 19.188 ha (19.49\%) and low flood hazard 
covered 1,689 ha (1.72\%).Flood incidents recorded each year resulted in crop failure and decreased production of rice crops in Karawang regency (Riadi et al. 2017) as shown in Table 5.

Table 5. Inundation area, crop failure area, productivity and loss of harvest

\begin{tabular}{|c|c|c|c|c|}
\hline Year & $\begin{array}{c}\text { Inudation } \\
\text { area (ha) }\end{array}$ & $\begin{array}{c}\text { Crop failure } \\
\text { area (ha) }\end{array}$ & $\begin{array}{c}\text { Produc-tivity } \\
\text { ton/ha }\end{array}$ & $\begin{array}{c}\text { Loss of } \\
\text { harvest } \\
\text { ton }\end{array}$ \\
\hline 2010 & 12,462 & 6,346 & 5,968 & 37,873 \\
\hline 2011 & 1,722 & 1,952 & 6,042 & 11,794 \\
\hline 2012 & 3,254 & 6,475 & 5,846 & 37,853 \\
\hline 2013 & 7,677 & 4,547 & 6,156 & 27,991 \\
\hline 2014 & 11,550 & 7,700 & 5,953 & 45,838 \\
\hline 2015 & 1,374 & 415 & 6,448 & 2,676 \\
\hline 2016 & 10,272 & 810 & 6,448 & 5,223 \\
\hline
\end{tabular}

Source:[17, 5] and The Calculation Results

Pond area with medium potential flood prone was 14,058 Ha, and with high potential was 4,088 $\mathrm{Ha}$ (Agustini and Suratijaya, 2014).

\section{Conclusions}

Land cover/land use changes in Karawang regency were analyzed spatially indicating that there was degradation of paddy fields, and an increase in pond extent. From 2000 to 2015 degradation of paddy fields was 21,909 ha, while the expansion of pond area was 16,355 ha. Coastal areas are alluvial lands that are naturally flooded areas. Flooding that occurred in Karawang resulted in a loss of rice production by an average of 24,178 ha per year. Minapadi land in flood-hazard areas was 11,273 ha, ponds located in the area of moderate flood hazard was 14,058 ha while ponds with very high prone to flood was 4,088 ha. It was predicted that until 2031 the paddy fields will continue to degrade and the remaining is predicted 88,007 ha, the pond area will remain about 24,207 ha and the population will be 2,826,579 people. Assuming fixed rice production and population continues to increase, food security or rice needs in Karawang regency can still be met, but the surplus of rice for national food needs will decline. In accordance with the condition of pond habitat, fish farmers were predicted to keep working, considering its good income to support family life. However, wetland degradation tended to reduce minapadi business. The dynamics of coastal changes and the threat of floods to aquaculture led to the creativity of fish farmers in reducing business losses by placing nets around ponds to assure that fish was not washed away by the flood.

To prevent land use change can be done with several attempts (a) to protect paddy fields from the land conversion process; (b) restrict the conversion of productive agricultural land into residential or industrial areas; (c) restrict the conversion of paddy fields and ponds into non-agricultural activities and (d) any land use application is checked for compliance with Regional Regulation Number 2 of 2013 on Spatial Planning of Karawang Regency in 2011- 2031.

\section{Acknowledgements}

We would like to thank the Geospatial Information Agency for providing TerraSAR-X DTM data and topographic maps. Also thanks to USGS Website for the ease of Landsat data access, the Faculty of Geo-Information Science and Earth Observation (ITC) for open source ILWIS 3.8 software and all parties who helped in this study, so this article can be resolved.

\section{REFERENCES}

[1] Agus F, Mulyani A. Judicious use of land resources for sustaining Indonesian rice self-sufficiency. Proceedings International Rice Conference, 12-14 Sept. Denpasar, Bali. Indonesian Institute of Rice Research, Sukamandi.2006.

[2] Lovapinka C. Valuasi Ekonomi Dampak Budidaya Ikan Di Tambak Dengan Alih Fungsi Lahan Mangrove Di DesaTambaksumur, Kecamatan Tirtajaya, Karawang. Bogor Agricultural university. 2014.

[3] Utojo, Mansyur A, Mustafa A, Hasnawi, and Tangko A.M. Pemilihan lokasi budidaya ikan, rumput laut, dan tiram mutiara yang ramah lingkungan di Kepulauan Togean, Sulawesi Tengah. J. Ris. Akuakultur, 2(3): 303-318.2007.

[4] Hasbi H, Bagus TP,Syaifudin. Budi Daya Ikan Bersama Padi (Minapadi) Sebagai UpayaUntuk Meningkatkan Pendapatan Petani. Jurusan Agronomi Fakultas Pertanian Universitas Muhammadiyah Jember. 2007.

[5] (BPS) Badan Pusat Statistik /Central Bureau of Statistics. Karawang In Figures. Badan Pusat Statistik, Karawang, West Java-Indonesia. 2016.

[6] http://glovis.usgs.gov/.Landsat-8 images year 2015

[7] Riadi B., BarusB., Widiatmaka., Yanuar M.J.P., Pramudya B.N.R.Identification and Delineation of Flood Hazard Areas with Spatial Modeling Using High-accuracy DEM Data in Karawang Regency. Proceedings of the 4th International symposium on LAPAN-IPB Satellite. 2017.

[8] Eastman J.R. IDRISI Taiga: guide to GIS and image processing. Worcester: Clark Labs.2009.

[9] Suriadarma A. Dampak Beberapa Parameter Faktor Fisik Kimia Terhadap Kualitas Lingkungan Perairan Wilayah Pesisir Karawang - Jawa Barat. Jurnal RISET Vol.21. 2011.

[10] Ashuri W.C. Keragaan Produksi dan Kelayakan Usaha Budidaya Ikan Sistem Minapadi. Balai Layanan Usaha Produksi Perikanan Budidaya Karawang. 2011. 
[11] Baig M.H.A., Zhanga L., Shuaiab T., Tonga Q. Derivation of a Tasselled Cap Transformation based on Landsat 8 at satellite reflectance. State Key Laboratory of Remote Sensing Sciences, Institute of Remote Sensing and Digital Earth (RADI), Chinese Academy of Sciences, Beijing, China University of Chinese Academy of Sciences, Beijing, China http://grindgis.com/blog/ vegetation-indices-arcgis. 2014.

[12] Buchanan B.P., Fleming M., Schneider R.L., Richards B.K., Archibald J., Qiu Z., Walter M.T. Evaluating topographic wetness indices across central New York agricultural landscapes. Hydrology and Earth System Science 18: 3279-3299. 2014.

[13] Chapman G.A., Young M.A., Gray J.M. Using Compound Topographic Index to Deliniate Soil Landscape Facets from Digital Elevation Models for Comprehensive Coastal Assessment. The Modeling and Simulation Society of Australia and New Zealand Inc.2005
[14] (BIG) Badan Informasi Geospasial /Geospatial Information Agency. Topographic and Toponym Mapping Centers. Technical Guidelines for Generalization of Indonesia's Topographic of Intermediate Scale Map. Bogor: Cibinong. 2014.

[15] Ramlan A., Solle M.S., Seniarwan. Dynamics and Projection of Land Use Change at Peri-Urban Region of Makassar City (Mamminasata Area). Proceedings Conference of Indonesia Society for Remote Sensing The $20^{\text {th }}$ (PIT MAPIN XXX). 2015.

[16] Noviyanti E., Rohmat D., Nandi. Pengaruh Usaha Budidaya Tambak Terhadap Kondisi Sosial Ekonomi Petani Tambak Di Kecamatan Cibuaya Kabupaten Karawang. Jurnal Antologi Pendidikan Geografi, Vol.4, Nomor 2, Agustus. 2016.

[17] (DPKPP) Department of Agriculture Forestry Plantation and Husbandry Karawang Regency., 2013 Laporan Kegiatan. 2012. 